\title{
MERZIFON CÖNKÜ
}

\author{
Metin HAKVERDİOĞLU
}

Dr. Öğr. Üyesi, Amasya Üniversitesi, metin.hakverdioglu@amasya.edu.tr ORCID: 0000-0002-9674-3292

Hakverdioğlu, Metin. "Merzifon Cönkü” idil, 57 (2019 Mayıs): s. 543-558. doi: 10.7816/idil-08-57-02

\section{$\ddot{\mathbf{O z}}$}

Amasya'nın en büyük ilçesi olan Merzifon yüzyıllar boyunca önemli bir kültür merkezi olmuştur. Bu merkez, edebî hayatımızın şekillenmesinde oldukça önemli bir yer işgal etmiş ve pek çok şaire ve şiir sanatını sevene yurt olmuştur. Merzifon'un Amasya'dan farkı bir kasaba olması ve halk ile divan şiirini bir arada yoğurabilecek bir konuma sahip olmasıdır. Çorum, Kastamonu, Sinop, Samsun gibi merkezlerin yolu üzerinde büyük bir yerleşim yeri olmak onu bu konuma getirmiştir. Kasaba, âdeta halk şairlerinin güzergahında bir dinlenme, soluklanma hanı görevi yapmıştır. Özellikle on sekizinci ve on dokuzuncu yüzyılda yaşayan şairlerin bu çevrede uğramak zorunda kaldıkları bir menzil olması, Merzifon'u şairlerin ve şiir severlerin merkezi haline getirmiştir. Dertli, Emrah, Nûrî, Aşı Ömer gibi önemli isimler Eyüp Sabrî gibi Merzifonlu şairlerin davetine icabet etmiş, merkezin sanat hayatına renk katmışlardır. Elimizde bulunan ve Merzifon Cönkü adını verdiğimiz el yazması eser işte bu ortamın doğurduğu nadide bir kaynaktır. Kendi kütüphanemize Merzifon'dan dahil ettiğimiz bu eserin en ilginç yönü, halk ve divan şiirlerini eşit olarak kaydetmesidir. İçerisinde Bâkî gibi büyük divan şairinden şiir olduğu gibi, halk şairlerinin aruzla yazılmış onlarca şiiri de vardır. Diğer taraftan, maniden koşmaya onlarca hece şiiri de bu cönkte bir araya getirilmiştir. Toplamda otuz iki şairden 161 şiir ihtiva eden cönk, Tokatlı Nûrî’nin şiirlerine ağırlık vermiştir. Şiirler, hece ile yazılmış koşma ve mani; aruzla yazılmış divan, sema'î, kalenderî, satranç, gazel, güfte gibi nazım şekillerindedir. Cönkte, toplam 98 aruz şiirine karş1lık, 63 hece şiiri mevcuttur. Çalışmamızda, Merzifon Cönkünün özelliklerini ve içerdiği şiirlerin ilk nazım birimlerini sunmayı amaçlamaktayız.

Anahtar Kelimeler: Merzifon Cönkü, divan şiiri, halk şiiri, cönk, hece ölçüsü, aruz ölçüsü 


\section{Giriş}

Türk edebiyatı bin yılı aşkındır iki temel kaynaktan doğmaktadır: halk şiiri ve divan şiiri. Bu iki kaynak karşılaştıkları günden beri birbirini etkilemiş ve yeni edebî ürünler ortaya koymakta birbirine yardımcı olmuştur. Bazen divan şairleri türküler yazarak veya maniden ilham alıp tuyuğ gibi nazım şekilleri üreterek halk şiirine yaklaşmış; bazen halk şairi sema'i, divan, kalenderi, satranç gibi aruzun belli kalıbı ile yazılan şiirlere meylederek divan şiirine gönül vermiştir. Bu iki şiir akımını birbirini küçümseyen şiir dalları olarak gösterenlerin aksine, bu akımların ortak yönleri yüzyıllar geçtikçe artmış ve on sekiz, on dokuzuncu yüzyıllarda en yakın ve ortak şiir dünyası ortaya konmuştur. Cönklere ve mecmualara giren şiirler artık hece veya aruz diye ayrılmamış, divan şairinden de halk şairinden de örnekler kaydedilmiştir. Özellikle Anadolu'nun edebî muhiti canlı olan yerlerde bu birliktelik en üst seviyeye çıkmıştır.

Amasya ve yöresi cönkler yönünden zengin bir muhit olarak bilinir. Bu cönklerden birini Prof. Dr. Şahin Köktürk (2007), Cönklerden Bir Cönk Amasya Cönkü adıyla yayımlamıştır. Bu eserde Âşık Kerem'in Kerem ile Aslı hikâyesi yanında Ahmedî, Âşık Boran, Âşık Ömer, Derviş Dede, Gevherî, Karacaoğlan, Kul Mustafa, Nazîfî, Sirrî gibi şairlerden şiirler bulunmaktadır.

Merzifon, edebî muhiti ve edebiyatçıları misafir etmesi ile meşhur Anadolu kasabalarından birisidir. $\mathrm{Bu}$ merkezde her dönem şair ve şiir baş tacı edilmiş, beğenilen şiirler kayıt altına alınmıştır. Elimizde bulunan Merzifon Cönkü adını verdiğimiz eser de bu hassasiyetin bir örneğidir.

Merzifon Cönkü, esası itibarıyla divan ve halk şiiri kardeşliğinin gözle görülen bir numunesidir. İçindeki şiirlerin yarısının aruzla, yarısının da heceyle yazılmış olması; divan ve halk şairlerini bir arada sunması hasebiyle bu adlandırmayı hak etmektedir. Aşağıda sebeplerini açıklayacağımız gibi bu eser münbit bir muhitin ürünüdür. $\mathrm{Bu}$ muhit, kendi şiir dünyası yanında etraftan davet edilen şairlerle zenginleşmiş ve güzel eserler ortaya koymuştur. Geleneğin emrettiği şekilde bu meclislerin verimi olan şiirler de cönklerde kayda geçirilmiştir.
Ele aldığımız ve şahsî kütüphanemizde olan bu cönk, tanınan şairlerin bilinen şiirlerini kaydetmesi yanında, adı henüz duyulmamış şairlere ve onların şiirlerine de yer vermektedir. Yine de bu cönkü orijinal kılan en temel vasfi, divan ve halk şiirini kardeş kılması ve aruz ile hece şiirlerini eşitlemesidir, diyebiliriz.

Cönkler ve mecmualar tam olarak incelenmeden tam bir Türk edebiyatı tarihi yazılamaz diyen Prof. Dr. M. Fatih Köksal (2016:169)'ın MESTAP adlı Mecmuaların Sistematik Tasnifi Projesi tanıtım yazısında, bizim elimizdeki cönkle de bire bir örtüşen şu bilgilere yer verilmektedir: "Şiir mecmualarında pek çok şairin (bazılarında sadece birkaç şairin) türlü nazım şekillerindeki şiirleri -genellikle- bir sıra, esas gözetilmeden bir araya getirilmiştir. En büyük etken derleyicinin "zevk"idir. Şairler değişik yüzyıllardan, farklı mezhep ve meşreplerden; şiirler değişik nazım şekillerinden, muhtelif uzunluklarda hatta Türkçenin yanı sıra Farsça veya Arapça olabilir. Kimi şiir mecmualarını derleyicilerinin kendileri de şairdir ve mecmuaya kendi şiirlerinden örnekler de alırlar. Mecmuaların çoğu bizzat derleyicisinin kaleminden çıkmışken, yani mürettip (derleyici) aynı zamanda müstensihken kimi mecmuaların müstensah nüsha olduğu fark edilir. Sipariş üzerine istinsah edilmiş ya da doğrudan müstensihin kendisi beğendiği bir şiir mecmuasını çoğaltmış olabilir" (Köksal, 2019: 2).

Bizim ele aldığımız cönk de Merzifon'da yașamış olan bir şairin zevkine uygun olarak toplad1$\breve{g} 1$ şiirlerden oluşmaktadır. Ancak bu zevke devrin diğer şairi ve Merzifon'un ileri gelenlerinden olan Eyüp Sabrî'nin de büyük etkisi olmuştur. Biliyoruz ki Merzifon'un edebî hayatına büyük şairleri- Tokatlı Nûrî gibi- davet eden kişi olarak bu isim öne çıkar. Prof. Dr. Orhan Bilgin (1992)'in bu şair hakkında yaptığı çalışmada verdi bilgilerden de bunu teyit edebilmekteyiz. Yine Köksal'ın dediği gibi elimizdeki cönk belli bir sıra gözetilmeden tasnif edilmiştir. Cönkü düzenleyenin divan şiirine ve aruza daha fazla meyli olduğunu buradaki seçimlerinden anlayabiliyoruz.

Cönk ve mecmuaların tasnifinde ve kataloglanmasında izlenecek yöntemlere örneklik teşkil 
eden Prof. Dr. Mehmet Fatih Köksal Kütüphanesi Türkçe Yazmalar Kataloğu (Köksal, 2018) benzeri çalışmaların çoğalması hem MESTAP gibi projelerde daha hızlı sonuç alınmasına hem de şahsî kütüphanelerde gizli kalan nüshalara erişimde fayda sağlayacaktır.

Meltem Yılmaz, bu çalışmaların yetersizliğinden bahsederek şu eksikliklere işaret etmektedir: "Fakat cönkler üzerinde henüz sistematik bir çalışma yapılmamış ve cönkler âdeta kendi kaderine terk edilmiştir. Sadece Kültür ve Turizm Bakanl1$\breve{g} 1$ tarafindan hazırlanan yazmalar.gov.tr adresinde kayıtlı bulunan 571 adet cöngün mevcudiyeti bile üniversitelerimizde yapılan yirmi civarındaki lisansüstü tez çalışması ve yine çok sınırlı sayıdaki diğer akademik çalışmaların nicelik olarak ne kadar yetersiz olduğunu açılamaya yeter." (Yılmaz, 2016: 167)

Bu çalışma ile bir cönkün daha akademik çalışmaya konu olması amaçlanmıştır.

\section{Cönkün Genel Özellikleri}

"Başta halk şairlerinin şiiri olmak üzere çeşitli folklorik bilgilerin kaydedildiği ve uzunlamasına açılan, sırtı dar, ensiz, deri kaplı deftere cönk denilir. Benzerliğinden ve şeklinden dolayı bu defterlere sığırdili yahut danadili de denilmiştir. Bazı kayıtlarda cönk yerine beyaz-1 büzürg ifadesi kullanılmıștır. Aydınlar da bu defterlere sefine-kâri demişlerdir." (Kaya, 2019:1)

Merzifon Cönkü adını verdiğimiz eserin dış özellikleri şöyle sıralanabilir:

1. Benzerliği ve şekli dolayısıyla dana dili-sığır dili denilen şekle sahiptir. 10,5x25 ebatlarındadır. Derleyeni belli değildir. İstinsah tarihi kadedilmemiştir.

2. Siyah mürekkeple yazılmış, okunaklı bir yazıya sahiptir. Yazı ta'liktir.

3. İlk sayfası ve sonlarda birkaç sayfası eksiktir.

4. Cilt cilt oluşturulan eserin ciltleri kalın bir iple bağlanmıştır.

5. Esere sayfa sayısı verilmiştir. 112 sayfadır. Ancak bazı sayfalar kayıptır bazı sayfalar ise tek- rarlanmıştır.

6. Cönkün kağıdı aharlıdır ve gayet sağlıklıdır. Filigranlı değil, sarı renkte kaba kağıttır.

7. Cönkün, genel durumuna ve öne çıkan şairlerin seçimine bakıldığında yaklaşık yüz yıllık olduğu tahmin edilebilir.

Cönkün içeriğinden de kısaca şöyle bahsedebiliriz:

1. Cönkte divan, semai, kalenderi, gazel, güfte, düstur, müfred ve satranç olmak üzere sekiz ayrı nazım şeklinde aruz ile yazılmış şiir mevcuttur.

2. Cönkteki 161 şiirin 98'i aruzla yazılmıştır.

3. Aruzla yazılan şiirlerin şairleri genelde halk şairleridir; ancak Bâkî gibi divan şairi olarak ünlenmiş şahıslardan da şiirler alınmıştır.

4. Cönkte 63 şiir hece ile yazılmıştır. Bunların çoğunluğu koşmadır. Ayrıca mani ve zencirî gibi örnekler de görülmektedir.

5. Cönkte toplam 32 şairden 161 şiir mevcuttur.

6. Tokatlı Nûrî cönkün en fazla şiiri aktarına şairidir. 36 şiirle en çok yeri o işgal eder. 18 hece, 18 aruz ile yazılmış şiiri mevcuttur.

7. Cönkün imlasının hatasız olması eserin divan şiirine vakıf birisi tarafından kaleme alındığını düşündürmektedir. Bu kişinin Merzifonlu bir şair olduğunu düşündüğümüz Fethî olması muhtemeldir.

8. Diğer şairlerin hece veya aruzla cönke alınan şiirleri ve sayıları şöyledir: Erzurumlu Emrah 3 hece, 8 aruz; Nazîf 1 hece, 9 aruz; Himmetî 1 hece, 2 aruz; Kerem 1 hece; Firâkî 1 hece; Ârif 11 aruz; Yesârî 1 hece, 3 aruz; Dertli 6 hece, 1 aruz; Şem ‘î 1 aruz; Gevherî 2 hece; Âşık Ömer 1 hece, 9 aruz; Hayrî 1 aruz; Visâlî 1 aruz, 1 hece; Zihnî 1 hece; Sürûrî 1 hece; Serbesî 1 aruz; Berkî(?) 1 aruz; Mısrî 1 aruz; Zahmî 1 aruz; Rizâ 1 aruz; Sabrî 8 aruz; Bâkî 3 aruz; Aşık Deli 1 hece; Feyzî 1 aruz; Bezmî 1 hece, 1 aruz; Gedâyî 2 hece; Fethî 5 hece Mahsunî 1 hece; Âşık Mustafa 1 hece; Cezbî 1 hece; Zahmî.

Cönke Merzifon Cönkü, adını vermemizin sebeplerini de şöyle izah edebiliriz: 
Cönkü elde ettiğimiz sahafin ifadesi ile bu eser Merzifon'dan elde edilmiştir. Cönkün içindeki şiirlerden ikisinde Fethî adlı şair-ki bu şairin cönkü tertip ettiğini tahmin ediyoruz- Merzifonlu güzel “Gülfadik”ten bahsetmektedir.

'Arż-1 ḥ̂lim yâre bir bir söylesem (Cönk, 112)

Bülbül gibi artar zârım Gülfadik

'Aşḳıı̌ deryâsını ben de boylasam

Ḥaşre dek söyünmez nârım Gülfadik

Zeytun gözleriňe ḳurbân olayım (Cönk, 115)

Şehr-i Merzifonda civân Gülfadik

Mạ̣v u helâkiňe dermân olayım

'Âşık oldum saňa inan Gülfadik

Cönke Merzifon Cönkü adını vermemizin bir sebebi de Merzifonlu ünlü bir aile olan Taşan sülalesinin yetiştirdiği Eyüp Sabrî’nin şiirlerine özel bir gazâliyât bölümü ayırıp bu şairi ön plana çıkarmasıdır. Orhan Bilgin'in bu şair hakkında yaptığı çalışmada belirttiği gibi bu şair, Merzifon'da yaşamış; genç yaşta ölmesine rağmen pek çok şair ile dost olmuş ve özellikle Tokatlı Nûrî’yi bu merkezde misafir etmiştir. "Tokatlı meşhur halk şairi Nûrî’yi sık sık Merzifon'a davet edip kendisiyle sohbet ve muşấ'arede bulunduğu bilinen Sabrî..." (Bilgin, 1992: 7)

Yukarıdaki sebeplerden, bu eserin, Eyüp Sabrî’nin edebî çevresinde bulunan Merzifonlu bir şair-ki bu Fethî olma ihtimali yüksektir- tarafından Merzifon'da tertip edildiği kanaati bizde hasıl olmuştur.

Cönke ad olarak koyduğumuz, "Merzifon Cönkü Bağlamında Hece-Aruz Kardeşliği” ibaresi ise, cönkte aruz ve hece ile neredeyse eşit sayıda şiire yer verilmesinden dolayıdır. Divan şairi Bâkî yanında, halk şairi olup aruzla yazan şairlerin şiirlerinden bol bol örnek vermesi, eserin bu yönünü ispatlamaktadır. Cönkte 98 aruz ölçüsü ile yazılan şiire karşı1ık 63 hece ile yazılmış şiir vardır. Hece olarak 56 koşma, 6 mani, 1 zencirî bulunan yazmada; aruzla, 26 divânî, 25 gazel, 14 sema'î, 13 kalenderi, 7 güfte, 1 santrancî, 11 müfred, 1 düstûr bulunmaktadır.
Prof. Dr. Cemal Kurnaz (1997)'ın 1srarla üzerinde durduğu halk ve divan edebiyatı yakınlığı bu cönkle adeta gözle görünür bir hal almıştır.

Cönkte, adı herkes tarafından bilinen şairler yanında ismi hiç duyulmamış şairler de mevcuttur. Tokatlı Nûrî gibi meşhurlardan, Fethî, Serbesî gibi adı duyulmamış mahalli şairlere kadar pek çok şair bu cönkte yer almıştır. Ayrıca mahlas kısmı eksik olduğu için şairi tespit edilemeyen 6 şiir de mevcuttur.

Cönkte çözülmeyi bekleyen noktalardan birisi de, Filip şeklinde okuduğumuz bir şairin bulunmasidir. 100)

Ḥayâliňi bilen çoḳdur sırıňa olmasun âgâh (Cönk

Görenler metḥiň eylesün ḳaşı siyâh gözi siyâh

Ḳuşatmış edirafıňa yeňi yıldız cemâl-i mâh

Bu bî-çâre Filib ḥüsnün̆ görüp didi maâşallah

Dudu dillim ince bellim ḳorḳaram ayrıluň benden

(بلف), şairin ismi eski yazı ile böyle yazılmıştır. Biz, Filib olarak okuduk; emin olmadığımız için isimsiz şiirler bölümüne kaydettik. Bu semâ‘î-i müseddesde muhtemelen gayri-müslim şivesi dolayısıyla kapalı, açık hece farkı da doğurmuştur; bu da kalıp uyumsuzluklarını doğurmuştur. Merzifon'un gayri-müslim tebaanın yoğun yaşadığı bir yer olması, bu isimlendirmemizi doğrulayabilir diye düşünmekteyiz. Ayrıca Eyüp Sabrî’nin divançesinde "Ohannes" redifli bir şiir yazması da bizim bu fikrimizi desteklemektedir. (Bilgin, 1992: 44)

$\mathrm{Bu}$ şairlerin ve şiirlerin üzerine yapılan çalışma olup olmadığını tespit etmek ayrı bir çalışma konusu olduğu için biz, birkaç şairin şiirlerinin hangi kaynakta bulunduğunu dipnot olarak göstermekle yetindik.

Cönkte Bulunan Şairler ve Şiirleri (İlk Nazım Birimleri)

Erzurumlu Emrah'ın hece ölçüsü ile yazdığı şiirleri (3 adet)

Koşma:

Ṭâ țfilldan berü ey gül-i ra'nâ (Cönk,38) 
Bülbülüm gülşeni gözler gözlerim

Dünya güzel olsa baḳmazam aṣlâ

Sevdigim cinânı gözler gözlerim

Koşma:

Sitem-kâr yâr ile ben geçinemem (Cönk, 52-53)

Felek başḳa ḳuluň çıraḳ edindi

Ya bir hû çek oda yansun ben gibi

Ya sevdâsın başdan ıraḳ edindi

Koşma:

Göňül sevdi ammâ hublar huyunı (Cönk, 88)

Cevr ü cefâsına liyâkạat mı var

Ol şâh-1 hûbâna vașf-1 hâlimi

Dilden 'arẑ itmeye cesâret mi var

Erzurumlu Emrah'ın aruz ölçüsü ile yazdığı şiirleri

(8 adet)

Divânî:

Mey degil meyhâneye varmaḳ merâḳımdır benim

(Cönk, 2)

Meclis-i mestâneyi görmek merâḳımdır benim

Sema'̂ิ:

Nigârâ sûz-1 'aşḳıňla derûnum oda yanmışdır

(Cönk, 5)

Kalupdır bu şirin cânım ḳafesde o da yanmışdır

Kalenderî:

Yâ Rab beni ol gözleri mestâne ḳavuşdur (Cönk, 40)

Bîmâr-i tenim luṭf idicek ol câna ḳavuşdur

Gazel:

Ey șabâ var söyle derdim yâre Allah 'aşḳına

(Cönk, 27)

Nâme-i zârım yetir gülzâre Allah 'aşḳına

Gazel:

Ey muḳaddes ḳudret 1ssı hâlıḳu'l-eşyâ hu dost

(Cönk, 98)

K'anı nûrdan kâ'inâtı var iden Mevlâ hu dost
Dîvân:

Bir perî peyker melek sîmâ güzellerden güzel

(Cönk, 98)

Ḥüsn-i a'lâ ḳ̂ameti bâlâ güzellerden güzel

Kalenderî:

Sevdim yine bir ḥûb-1 dilârâ pek iler mi (Cönk, 106)

Elbetde göňül vașlını ister de dilerdi

Kalenderî:

İtdi beni bir yâr-i perî şân iki yüzden (Cönk, 107)

Kâkülleriň itdigi perîşân iki yüzden

Tokatlı Nûrî’nin hece ölçüsü ile yazdığı şiirleri

(18 adet)

Koşma:

Nerde ḳaldı seniň ahd ü emânı̌ (Cönk, 4)

Cân verince cevr oduyla yaḳan yâr

Yine îmâ eder ḳaşın̆ kemânı̌

Kirpikleriň can evime çaḳan yâr

Koşma:

Başıň içün olsun seḥer yelleri (Cönk, 4)

Bir haber ver dâr-1 yâre gidersen

Baḳ beni aňar $\mathrm{m} 1$ şirin dilleri

O kâkül-i müşki-bâre gidersen

Koşma:

Felek șayısuz odlara yandım (Cönk, 5)

Pervâneniň olsun nâr şimden gerü

Ben âb-1 vișâle ḳandım boyandım

Baňa bu dert yeter kâr şimden gerü

Koşma:

Baňa ḳan yutturur șaḥbâ-yı hicrân (Cönk, 9)

Bilmem bu hasretlik gider mi böyle

Ben mi tedbîrimde eyledim noḳșan

Yoḳsa tecelli-i ḳader mi böyle

Koşma:

Bülbül olub düşdüm ḳazâ-yı aşḳa (Cönk, 10) 
Bir nev-nihal gül fidânın̆ ucundan

Șaldım ser ü cânı belâ-yı aşḳa

Melek-meşreb bir civânıň ucundan

Koşma:

Ey ḩubların̆ şâhı serv-i bülendim (Cönk, 31)

Nedir bu sendeki divâne gözler

Ey lebleri şirin nâzik efendim

Eyledi bendesin şâhâne gözler

Koşma:

Göňül bir yâr sevdi 'âlem içinde (Cönk, 33)

Görenler o yâre disün mâşallah

Oḳunsun o yârin mâh-1 cemâli

Aḥsenü'l-Ḩâlıḳın tebârekallah

Koşma:

Devrine aldanma sen bu dünyânın̆ (Cönk, 34)

Durmaz bir ḳarâra döner bu dünyâ

...

....

(Son dörtlük)

Nûrî bu menzile eyle bir tedbîr

'Âḳıbet olusuň dâmen-i esîr

Çünki bu yerin ki adı oldı sır

Seni de yer vara vara bu dünyâ

Koşma:

Bize hicrân düşmüş kilk-i ezelden (Cönk, 35)

Levḥ üzre ismimiz ḳaralanınca

Yâr serde sevdâyı câme-i 'aşḳıň

Gösteririm pâre pârelenince

Koşma:

Zencir-i zülfüňden bî-nevâ gön̆ül (Cönk, 36)

Ne yüz buldı ne ḳurtuldı ne çâre

Bir seniň yoluňda gülşen-i ‘ömrü

Geçdi gazellendi șoldı ne çâre

Koşma:
Ġarip göňlüm sensiz ârâm eylemez (Cönk, 37)

Ya sen nice iňliyorsun̆ bensiz yar

Serv-i ḳaddiň görüp ḩırâm eylemez

Kalem ḳaşı sîm gerdanı beňsiz yar

Koşma:

'Aceb ben ne didim o şîve-kâre (Cönk, 39)

Yine bugün yüz göz egri ḳaş egri

Yıḳmış fesi çekmiş re's-i küffârı

Servi nâzım kesmiş zülfi baş egri

Koşma:

Bu sûz-1 ẓulmetden dîvâne göňül (Cönk, 42)

Neyleyim bir kerre âzâd olaydı

Cevriyle yaḳılmış vîrâne gön̆ül

Nâ'il-i vașl olup âbâd olaydı

Koşma:

Ben țatlı cânımdan bezdim uṣandım (Cönk, 44)

Geçmediň cefâdan sen daha güzel

Sirişk-i la'limle ḳana boyandım

Bâri bir inșaf it baḳ bana güzel

Koşma:

'Ömrüm iḳliminden olduḳ müberrâ (Cönk, 46)

Arada bir derd-i tecellî ḳaldı

Bize böyle diye taḳdîr-i Mevlâ

Anca bu ḥaṭırda tesellî ḳaldı

Koşma:

Sen bugün bir 'âdil 'âlî-himemsiň (Cönk, 53)

Bir avuç ḳanımdan geç efendim geç

Mürüvvet baḥrisin șâhib-keremsiň

Baḳma noḳșânından geç efendim geç

Koşma:

Ḩazân ile geçdi gülşen-i bostân (Cönk, 56)

Eyle derdli bülbül zâr garîb garâb

Harâba yüz țutdı bezm-i gülistân

Ag̉la şimden girü var ġarîb garîib 
Koşma:

Biz bülbül-i bâg̀-1 'aşk-1 elest (Cönk, 64)

Vech-i bâkî gülsitânı bekleriz

Şarâb-1 elestden bir nice mestiz

Bahrr-i dilden dil-feşânı bekleriz

Tokatlı Nûrî’nin aruz ölçüsü ile yazdığı şiirleri

(18 adet)

Divânî:

Aḳdı zülfün̆ kişveri ruḥ̣̂âre devrân gösterir (Cönk, 2)

Esb-i nâzuň halḳa-i devvâre devrân gösterir

Kalenderî:

Derd-i dilim açsam eger âh cânım efendim (Cönk, 6)

Bir derdim olur biň ḳadar âh cânım efendim

Düstûr:

Yine aldı ġam u efkâr dil-i dâg-1 tenin (Cönk, 20)

Acımaz mı yüregiň merḥametiň yoḳ mu seniň

Ne revâ goncaya cevri hele serv-i semeniň

Acımaz mı yüregin merḥametiň yoḳ mu seniň

Kalenderî:

Ey yâr beni sen âteş-i hicrâna bıraḳma (Cönk, 20)

Yaḳdın̆ bu ḳadar bâri yeter cânımı yaḳma

(Ahmet Talat, 1933: 139)

Kalenderî:

Ey mâh-1 felek-câh-1 sipihriň ceberûtı (Cönk, 21)

Sensiň bu hümâ-sâye-i mülküň melekût1

(Ahmet Talat, 1933: 141)

Dîvân:

Rah-1 aşḳa itdi dil çün iḳtidâ yâ Rabbenâ (Cönk, 22)

Peyk-i tevfị̂iň ona ḳıl reh-nümâ yâ Rabbenâ

Dîvân:

Güller açdıḳça ruh-1 zîbâlarıň dört beş bölük

(Cönk, 23)

Eksik olmaz bülbül-i şeydâların dört beş bölük

(Ahmet Talat, 1933: 112)
Semâ‘̂̂:

Sana ey mehliḳ̂ pek nâz ile bir nâme gönderdim

(Cönk, 23)

Seniň billûrıňa lâyıḳ mülevven câme gönderdim

Kalenderî:

Gel meclise șofî hele bir diňle bu sazı (Cönk, 25)

Fehm et ki bu sazın̆ nedir Allah niyâzı

Satrancî:

Ey cân-1 'âlem her sırra maḥrem ve’y gonca gül-fem gâyet güzelsin (Cönk, 26)

Ey cân-1 'âlem bir ince belsin her sırra mahremsin bî-bedelsin emelsin

Gâyet güzelsin sen bî-bedelsin bir ince belsin tûl-i

(Ahmet Talat, 1933: 171)

Gazel: (Ahmet Talat, 1933: 119)

Ey ḥekîm-i vaḳt olan gel yanıma Allah içün

(Cönk, 27)

Bir 'ilaç it derd-i bî-pâyânıma Allah içün

Dîvân:

Nâle ḳ̂l ey dil bugün ehl-i șafânıň zevki var

(Cönk, 29)

Ḥandeler eyler gülistânı sivânıň zevki var

Kalenderî:

Bülbül gibi gül ġonca vü şâh-1 emelim yok

(Cönk, 39)

Derd-i dili teskîn idecek bir mạ̣alim yoḳ

Semâ‘̂̀:

Dem-i eşkim töküp âh pâyına yüz sürdügüm demler

(Cönk, 41)

Dilerdim yâri Ḥaḳdan ol vaḳit ahşam ḳarîb olsa

Semâ‘̂̂:

Ferâgat eyle gel göňlüm ümîd-i vașf-1 dilberden

(Cönk, 41)

Bilürsin ki vefâ gelmez cihân içre güzellerden 
Semâ‘̂̂:

Hezâra âhı gaayri ol gül-i handânı çoḳ görmez

(Cönk, 49)

Sahurlarda varıp kûyundaki efgânı çoḳ görmez

Dîvan:

Seyre çık ey dil temâşâ it ne cândır çifteler

(Cönk, 56)

Dehride hem-tâsı yoḳ nâzik-miyândır çifteler

Semâ‘̂̂-yi Müseddes:

Olupdur zֵât-1 pâkiň Ḥaḳ ḥabîb-i Muștafâ cânâ

(Cönk, 95)

Zuhûruň rạ̣metullah-1 sebil ḳıldı Hüuâ cânâ

Cemâl-i Pertev-i nûruňla doldı mâ-sivâ cânâ

Münevverdir yüzüňden ser-be-ser 'arż u semâ cânâ

İki ‘âlem bulupdur âb-1 rûyuňdan nümâ cânâ

Ki seniň cümleniň sultânı fahrr-i enbiyâ cânâ

Nazîf'in hece ölçüsü ile yazdığı şiirleri (1 adet)

Koşma:

İflaḥ olmam ben bu dertden ölürüm (Cönk, 3)

Derdime bir çare bul ḳara gözlüm

Korḳarım ki gurbet elde ḳalırım

Yine görünmedi yol ḳara gözlüm

Nazîf' in haruz ölçüsü ile yazdığı şiirleri (9 adet)

Gazel:

Virseler alma saňa bir akç̧eye dünyâyı hep (Cönk,66)

Köhn olur her dem giyerseň ațlas-1 dîbâyı hep

Gazel:

Dâr-1 miḥnetde ferâh-yâb olması ag̉eb ‘acîb

(Cönk, 67)

Fısk ile firdevse nâ'il olması ag̉reb 'acîb

Gazel:

$\mathrm{Bu}$ fenâ 'âlemde âyâ bilmedim bilmem ne var

(Cönk, 68)

Cân virüp 'arzuya dâ'im bilmedim bilmem ne var
Gazel:

Her ne geldi yâ gelür aḥvâlini Allâh bilür (Cönk, 68)

'Abdiniň her ḳıldıġın ef'âlini Allâh bilür

Gazel:

Hâne-i ḳalbi demâdem ḳul yıḳar Allâh yapar

(Cönk, 69)

Dest-i ḳudretle binâyı ḳul yıḳar Allâh yapar

Gazel:

Şem‘a-yı nûr-1 hidâyet dâ'imâ par par yanar

(Cönk, 70)

Şemşir-i şân-1 şeri'‘at dâ’imâ par par yanar

Gazel:

Bir iki gün zevḳ içün 'uḳbâyı taḥrîb eyleyüp

(Cönk, 71)

Ol 'adûnuň teşviḳiyle râh-1 şeyțân istemem

Gazel:

Bilmez evșâfın̆ seniň râhıňda ḳurbân olmayan

(Cönk, 72)

'İzzetiň fehm eylemez 'aşḳın̆la nâlân olmayan

Gazel:

Nâ'il olmaz feyż-i Ḥaḳka dilde 'irfân olmadan (Cönk, 73)

Gül açılmaz tâgi kalpde tâ ki bârân olmadan

Himmetî’nin hece ölçüsü ile yazdığı şiirleri (1 adet)

Koşma:

Ġarib bülbül gibi artmaḳda zârım (Cönk, 50)

Konca gül-ruhsârım nerdedir şimdi

Giceler ḳan döker çeşm-i giryânım

Nazlı şive-kârım nerdedir şimdi

Himmetî’nin aruz ölçüsü ile yazdığı şiirleri (2 adet)

Dîvân:

Dehr içinde bir perî șûret ki gördüm nâzenîn

(Cönk, 8)

Bârekallah hüsnüne ḳıldım besendi âferîn 
Semâ‘̂̂:

Çekilmiş ḳudreti Ḥaḳdan cemâliň şevḳi bir perde

(Cönk, 94)

'Aceb hem-tâ olur mı hüsniňe bir gaayri dilberde

Fedâ cân eylerim elbet yolunda sen gibi merde

Neler var pek naẓar ḳıl 'âşıłııı̌ esrârına ebrde

Değil bir kimsede meylim faḳat sen şûh-1 gül-terde

Bana raḥm eyle sulțânım perîşân hâalimi gör de

Kerem'in hece ölçüsü ile yazdığı şiirleri (1 adet)

Koşma:

'Elâ gözlerine ḳurbân oldugum (Cönk, 106)

Hep seniň derdiňe yanar ag̉larım

Güllere 'arż idem 'arż-1 hâlimi

Elleriň yanında görür ag̉larım

Firâkî’nin aruz ölçüsü ile yazdığı şiirleri (1 adet)

Gazel:

Coşdı göňlüm sel gibi çag̉lar o yâriň semtine

(Cönk, 108)

Rûz u şeb muḥabbetim bağlar o yâriň semtine

Ârif'in aruz ölçüsü ile yazdığı şiirleri (11 adet)

Güfte:

Ald1 'aḳlım bir perî șûret bugün pek yandım âh

(Cönk, 10)

Mest olup ḳaldım görünce eyledi ḥâlim tebâh

Güfte:

Sa`îd olsun efendim 'abd-i mezîdin sa ‘îd olsun

(Cönk, 10)

Bu dil şevḳinle gamamdan nâr-1 hạasretden ba ‘îd olsun

Dîvân:

Esîr etdi dil-i dîvânesin gîsûların câna (Cönk,11)

Ne zâlimdür o çeşm ü ġamze-i cadûların cânâ

Dîvân:

Derd-i gamdan dehrde bir kere âzâd olmadım

(Cönk, 12)
Günlerim ekdâr ile hep geçdi âbâd olmadım

Güfte:

Küçücüksün diyerek ḳaş-1 kemânım büyüdüň

(Cönk, 13)

Uzayıp servi gibi tâze fidânım büyüdüň

Güfte:

'Asker-i İslâma serdâr oldu gitdi dâverim (Cönk, 13)

Çoḳ du'âlar eyleyip gönderdi anı enverim

Güfte:

Bahâr eyyâmı da gülşende feryâd-1 hezâr eyler

(Cönk, 13)

Döker yaşın gözünden rûz u şeb çoḳ âh u zâr eyler

O mesken kendüye güyâ o bâg-1 kâm-dâr eyler

Cigerden âh ider dâ'im ḥisâbın bî-şümâr eyler

Yeşil destâr içinden gonce bir ḩoş âşikâr eyler

Görünce bülbül-i şeydâ figânı ihtiyâr eyler

Güfte:

Meclîsde bu şeb ț̂ti semendân bana düşdi (Cönk, 15)

Sehmimde şeker ruḥları elvân bana düşdi

Gazel:

İşde geldim yâ İlâhî baş açık dîvânıňa (Cönk, 16)

Beni (......) itme el-amân hüsrânın̆a

Güfte:

Ne gün teşrîfiňiz âyâ ne hoş geldiň șafâ geldiň

(Cönk, 17)

Kademler bașdıňız bu yana hoş geldiň șafâ geldiň

Semâ‘̂i:

Sükür olsun vücûd iḳlîmime Rabbim şifâ verdi

(Cönk, 18)

Yatarken bî-mecâl hâlimde yekden bir devâ verdi

Yesârî’nin hece ölçüsü ile yazdığı şiirleri (1 adet)

Koşma:

Göster cemâliňi köz gibi yüzüň (Cönk, 43)

Dilber bu cemâliň mübtelâsıyuz 
Merḥamet kânıdır alur büryâne

Göňüller şâhınıň âşinâsıyuz

Yesârî’nin aruz ölçüsü ile yazdığı şiirleri (3 adet)

Semâ‘̂̀:

Didim cânâ ser-i zülfün̆de dil benddir boşanmaz ya

(Cönk, 20)

Dedi kûy-1 dilârâsından 'âşııllar uṣanmaz ya

Semâ‘̂̂:

Ne bilem dâmen-i yardan kesildi bu elim yâ Rab

(Cönk, 48)

Revâ mı âhla zârdan șolsa gonca-yı gülüm yâ Rab

Kalenderî:

Ṭâkat mı ḳlur bende-i üftâde efendim (Cönk, 86)

'Âşı̣ olalı ben sana dünyâda efendim

Dertli’nin hece ölçüsü ile yazdığı şiirleri (6 adet)

Koşma:

Yâr neden țatlanır neden ḩoşlanır (Cönk, 24)

Bilmem bu yâr neniň mübtelâsıdır

Gâh sögünür gönül gâh ateşlenir

Ne çâre çekmeyem 'aşk belâsıdır

Koşma:

Bir yere cem‘ olmuş birkaç ‘âşıḳlar (Cönk, 36)

İnler birbirine meydân iderler

Mest-i elest olmış ḳalb-i șâdıḳlar

Muhabbet sırrını nihân iderler

Koşma:

Ḩațırına düşüp șorarsa hâalim (Cönk, 43)

Kirpikleri siyâh ḳalem ḳaşlı yâr

Zikri fikri çıḳmaz dilimden dâ'im

Anadan gülmedik garî̀b başlı yâr

Koşma:

İlâhî ẓulmete düşürüp yolum (Cönk, 84)

Miḥnet-i dünyâyı bana (mı) virdiň

Dergâhıňda naṣıl baḥtı kem ḳulum
Cevr ile cefâyı bana (mı) virdiň

Koşma:

Leyle-i zuulmetde pervâne diller (Cönk, 85)

Yanar nâr-1 'aşḳa bir cevâp itmez

Feryâdı bülbülden şerm itdi güller

Meger itdiginden yâr ḥicâp itmez

Dertli'nin aruz ölçüsü ile yazdığı şiirleri (1 adet)

Gazel: (Müseddes) (Arslan ve Doğan, 2009: 218)

'Arż-1 ḥâlim râya düşdüm çog̉ efğân eyledim

(Cönk, 102)

Leyli-veş beyt-i hazînde hûn-1 giryân eyledim

Câme-i șabrım țutup çâk-i girâbân eyledim

Șoyunup 'abdal olup bu çeşmi gîrân eyledim

Kendimi 'aşḳıň yolunda şöyle ḳurbân eyledim

Gerden-i mecrûhı̣ımı kesdim ḳızıl ḳan eyledim

Şem ‘̂̂’nin aruz ölçüsü ile yazdığı şiirleri (1 adet)

Dîvân:

Esme ey bâd-1 șabâ zülf-i dilârâ șarșilur (Cönk, 24)

Deprenirse bir teli rûyunda dünyâ șarșılur

Gevherî’nin hece ölçüsü ile yazdığı şiirleri (2 adet)

Zencirî:

Fig̣ân eylemesün yoḳ yere bülbül (Cönk, 26)

Bülbül-i dal bilir gül ḳıymetini

Ḳıymetini kendi ne bilsin göňül

Göňül veren bilir dil ḳıymetini

Koşma:

Tecrübe eyledim kendimi gördüm (Cönk, 89)

Hercâî sevmeden göňül farımış

Ben kendimi 'âşı̣ onu yâr dirdim

Ne ben 'âşı̣ mışım ne ol yâr imiş

Aşık Ömer (Elçin, 1987)'in hece ölçüsü ile yazdığı

şiirleri (1 adet)

Koşma:

Diňle ḥasb-i ḥâlim benim efendim (Cönk,109) 
Yerden göge degin senden şikâyet

Yâ helâk iderim kendi kendimi

Yâ sen bu nâzın̆dan eyle ferâgat

Aşık Ömer'in aruz ölçüsü ile yazdığı şiirleri (9 adet)

Dîvân:

Bir güzeller şâhı gördüm âyet-i ḳadr-âne yüz

(Cönk, 28)

(Bir) Naẓar ḳıldım (mâh) yüzüne sûre-i Raḥmâne yüz

Bir iki âyet oḳudum gördüm anın emrini

'Aş̣k olan hemân bilsün sevdigim civâne yüz

Dîvân:

Ey gönül deryâ-yı 'aşḳa dalmag̉a şüpheň mi var

(Cönk, 31)

Felegiň tondan tona atmamaga şüphen mi var(?)

Dag̉ıdup gülistan-1 ‘ömrüm eserse bâd ecel

Șararup ḥazân misâli șolmag̉a şüpheň mi var

Dîvân:

Acıyın dostlar benim gül yüzlü yârim aldılar

(Cönk, 99)

Nice ḳan ag̉lamayayım çeşm-i siyâhım aldılar

Nice bu hûnî ḥarâmî taňrıdan ḥavf eylemez

El urup ḥançer țaḳılan țog̉rı şâhım aldılar

Dîvân:

Ben saňa mübtelâ oldım cemâliň görsem olmaz mı

(Cönk, 101)

Yanaġıň gül gül açılmış gülüňi dersem olmaz mı

Gazel:

Yâ İlâhî sen beni insâna muhtâc eyleme (Cönk, 103)

Olur olmaz nâ-ḥak-1 nâ-dâna muḥtâc eyleme

Ol ḥabîbiň fahrr-i 'âlem Mușțafânıň 'aşḳına

Çâresüz ḳılup (da) dûşîmâna muhtâc eyleme

Dîvân:

Ben saňa göňül vireli bu cihânda gülmedim (Cönk,
110)

Geçdi ‘ömrüm miḥnet ile bir șafâsın görmedim

Başıma bunca felâket geldi ben uṣlanmadım

Bed du'â bilmem güzel Mevlâya șaldım ben seni

Dîvân:

Çün güzelim zülfi dâlım boyuna baḳmaḳ içün

(Cönk, 111)

Bu vücudum şehri vîrân hâț̣ırım yıḳmaḳ içün

Âteş-i hicr ile dilber bag̉ımı yaḳmaḳ içün

Kaş̧ların çifte țabanca sîneme çaḳmaḳ içün

Dir ki ‘Ömer medḥ ideyim ḥublarıň serdârını

Mâh cemâliň görse 'âşı̣ terk ider her varını

Dîvân:

Cân u dilden mâ'il oldum bu șaçı Leylâya ben

(Cönk, 111)

Dili bülbül șaçı sünbül ḳaşları zafrâya ben

Gice gündüz ḥasretiňden ciğerim ḳan ağladı

Bir oňulmaz derde düşdüm uğradım ġavġâya ben

Hayrî’nin aruz ölçüsü ile yazdığı şiirleri (1 adet)

Dîvânî:

Bu reh-i ‘aşk üzere hem-tâyı bulmaḳdır hüner

(Cönk, 29)

Nice hịmet içre dür-yektâyı bulmaḳdır hüner

(Bu) cihânda künc-kanâ‘at mülkünün̆ şâhı olup

Semt-i 'âlî devlet-i Dârâyı bulmaḳdır hüner

Visâlî’nin aruz ölçüsü ile yazdığı şiirleri (1 adet)

Dîvân:

Kande gitdi ol civânım gül-fidanım görmedim

(Cönk, 30)

Vech-i mürşîd-i münevver bedr-i mâhım görmedim

Zihnî’nin hece ölçüsü ile yazdığı şiirleri (1 adet)

Koşma:

Kâtip sen yaz șabâ sen de kerem ḳıl (Cönk, 35)

Götür 'arẑ-1 hâalim yâre tez elden 
Nâzikdi efendim nezâketlü yaz

Gönderelim o dildâre tez elden

Sürûrî’nin hece ölçüsü ile yazdığı şiirleri (1 adet)

Koşma:

Yeter cevr eylediň ey ruḥ-1 mâhım (Cönk, 45)

Niceler bu țarz-1 revişden geçdi

Sana kâr itmedi zerrece âhım

Yeter âhım kûh-1 keşişden geçdi

Serbesî’nin aruz ölçüsü ile yazdığı şiirleri (1 adet)

Dîvân:

Ey perî bülbül gibi efkâre düşdüm gel yetiş

(Cönk, 48)

Aḳdı sel gibi hemân 'ummâna düşdüm gel yetiş

Tâ ḳıyâmet ḥaşr olanda ag̉laram Yâḳub gibi

Ḥażret-i Yûsuf gibi zindâne düşdüm gel yetiş

Berkî’nin(?) aruz ölçüsü ile yazdığı şiirleri (1 adet)

Semâ‘̂̂:

Göňül bu derd-i ‘âlemde zekâvet olmamız yegdir

(Cönk, 55)

Merîten 'âli meşrebde lețâfet olmamız yegdir

Mısrî’nin aruz ölçüsü ile yazdığı şiirleri (1 adet)

Gazel:

‘İlim baḥri vücûd esdâfınıň dür dânesiyim ben (Cönk, 57)

Ma'ârif kenz-i dil vaș̣âfınıň vîrânesiyim ben

Zahmî’nin aruz ölçüsü ile yazdığı şiirleri (1 adet)

Gazel-i Müseddes: (Arslan ve Doğan, 2009:772)

Dilâ tecdîd-i matem ḳ1l bugün mah-1 Muḥarremdir

(Cönk, 58)

Melâik ins ile cinnî bugün hep ehl-i mâtemdir

Velâyet şâhınıň yâ hû şehîd oldug̉u bu demdir

'Adüvv-i ekberim ancaḳ benim bir iki âdemdir

Birisi Şimr-i Zülcevşen birisi İbn-i Mülcemdir

Bulara dâ'imâ la‘net dimek mü’mîne elzemdir
Rızâ'nın aruz ölçüsü ile yazdığı şiirleri (1 adet)

Gazel:

Șofiyâ devrâna gel Allâh hû yâ hû diyü (Cönk, 64)

Şevḳ ile meydâne gel Allâh hû yâ hû diye

Sabrî’nin aruz ölçüsü ile yazdığı şiirleri (8 adet)

Kalenderî: (Bilgin, 1992: 47)

Yandım o perî peykere ḥayfâ ele geçmez (Cönk, 74)

Eyler se de baḳışları îmâ ele geçmez

Kalenderî: (Bilgin, 1992: 46)

İncitme beni ey güzelim cevriňi az it (Cönk, 74)

Gâh va'd ü viṣâl eyle bana gâhice naz it

Gazel: (Bilgin, 1992: 23)

Âh kim sevdim diyü ol mâh-rûy-1 enveri (Cönk, 76)

Başıma ol dem nihâd oldı belânıň efseri

Semâ‘î: (Bilgin, 1992: 38)

Severseň ger dilâ bir dilber-i derdân-1 devrân sev

(Cönk, 77)

Melâhat gülşeninde zîb-nevres verd-i handân sev

Gazel: (Bilgin, 1992: 33)

Her gören ol dilberi tag̉yîr-i aḥvâl eylemiş (Cönk, 77)

Farṭ-1 ḥayretden zebânın şöyle kim lâl eylemiş

Kalenderî: (Bilgin, 1992: 29)

Misliň bulamam ey güzelim dehrde teksin

(Cönk, 90)

Sen șûret-i âdemde velî şûh-1 meleksin

Kalenderî: (Bilgin, 1992: 46)

Yâ Rab bu kuluň fevz ü felâh semtine varmaz

(Cönk, 90)

Girdâb-1 ma‘âṣ̂ye düşer kimse çıḳarmaz

Semâ‘î: (Bilgin, 1992: 36)

'Aceb bir ben miyim dûçâr olan efg̉âna bilmem ki

(Cönk, 93)

Veyâ 'âlemde rûzî mi bu her insâna bilmem ki

Bâkî’nin aruz ölçüsü ile yazdığı şiirleri (3 adet) 
Gazel: (Küçük, 1994: 268)

Çeşm-i pür-hûnum yoluňda eşk-bâr itsem gerek

(Cönk, 78)

Ayaġın tozına gevherler nišâr itsem gerek

Gazel: (Küçük,1994: 260)

Câm la 'liňdir seniň âyîne rûy-1 enveriň (Cönk, 79)

Ad1 var Câm-1 Cem ü Âyîne-i İskenderiň

Gazel: (Küçük, 1994: 151)

Göňül her naġme kim çeng-i gamıňda ihtirâ‘ eyler

(Cönk, 94)

Koyup elden felekde Zühre sazazın istimâ‘ eyler Aşık Deli'nin hece ölçüsü ile yazdığı şiirleri (1 adet)

Koşma:

Ey ag̉alar ben bugün pür ayıldım (Cönk, 80)

Ṭag̉ başına țuman ne güzel uymuş

Şükür olsun ol yaradan Hü̈dâya

Îmân dîn İslâma ne güzel uymuş

Feyzî’nin aruz ölçüsü ile yazdığı şiirleri (1 adet)

Gazel:

Dehr içinde mürşid-i dânâyı bulmaḳdır hüner

(Cönk, 81)

Ögrenüp dersin dil-i ma‘nâyı bulmaḳdır hüner

Bezmî’nin aruz ölçüsü ile yazdığı şiirleri (1 adet)

Müseddes:

İşitdim dilber-i ra'nâ bugünlerde kederlenmiş

(Cönk, 82)

Baňa cevr ü cefâ efzûn idüp her dem hünerlenmiş

Seniň destiňden ey dilber eḥak âdem degerlenmiş

Seni görmek içün şâhım raḳîler hep siperlenmiş

Yanag̉ın çevresi dilber siyâh beňler biberlenmiş

Bana emdirmediň z̦âlim beyâż gerdân şekerlenmiş

Bezmî’nin hece ölçüsü ile yazdığı şiirleri (1 adet)

Koşma:

Kemân ebrûlarıň âhû gözleriň (Cönk, 87)
Mecnûn gibi ḳ̂lar dîvâne meni

‘Âşıḳı mest ider şîrin sözleriň

Rüsvâ-y1 'aşḳ ider cihâne meni

Gedâyî’nin hece ölçüsü ile yazdığı şiirleri (2 adet)

Koşma:

Sevdâ-y1 'aşkı̣̌la țolanayım mı (Cönk, 91)

Böyle ḳalb-i maḥzûn dîdeleri yaş

Ateş-i hicriňle çok yanayım mı

Raḥm eyle hâalime gel ey bağrı țaş

Koşma:

Gülşen-i ‘âlemde ey gül-i ra'nâ (Cönk, 91)

Nedir çıțır pıṭır bu sivilcikler

Demez âyetlerin oḳursun ammâ

Lâleler ḳan ag̉lar âh çeker güller

Fethî’nin hece ölçüsü ile yazdığı şiirleri (5 adet)

Koşma:

Bir lebleri ra'nâ geldi yanıma (Cönk, 92)

İtdi hâatemini bergüzâr baňa

İnșaf eyle dilber geriye ḳalma

İtdigin cefâlar yeter kâr baňa

Koşma:

'Arż-1 hâlim yâre bir bir söylesem (Cönk, 112)

Bülbül gibi artar zârım Gülfadik

'Aşḳıň deryâsını ben de boylasam

Ḥaşre dek söyünmez nârım Gülfadik

Koşma:

Ziynet-i dünyâya meyil mi virem (Cönk, 113)

Aldadır âdemi dünyâ naḳışı

Vefâsızdır (gidip) gülün mi derem

Ḥuẓurında vardır onuň oynaşı

Koşma:

Âteş-i 'aşḳıyla yanıp ag̉larken (Cönk, 114)

Yandı ciger şimdi göz göz oldı gel

Nehr-i Ceyhûn gibi țurmaz çaġlarken 
Ṭolġa boyum aşup düpdüz oldı gel

Koşma:

Zeytun gözleriňe ḳurbân olayım (Cönk, 115)

Şehr-i Merzifonda civân Gülfadik

Maḥv u helâkiňe dermân olayım

'Âşık oldum saňa inan Gülfadik

Mahsûnî’nin hece ölçüsü ile yazdığı şiirleri (1 adet)

Koşma:

Göreli çeşmiňi ey ḳaşı kemân (Cönk, 97)

Beňzetdim rûyıňı güle sevdiğim

Zerrece göğsünde yoḳ mıdır îmân

'Âşı̣ı güldürdün ele sevdiğim

Âşık Mustafa'nın aruz ölçüsü ile yazdığı şiirleri

(1 adet)

Gazel:

Çoḳ zamândır intizâarım ḳaşı yâyı görmedim

(Cönk, 104)

Yerde midir gökde midir ol hümâyı görmedim

Gün gibi bilmem (neden) ġam hânesin yüz (biň) ider

Sîmleri şems ü ḳamerden ḥüsni ayı görmedim

Cezbî’nin hece ölçüsü ile yazdığı şiirleri (1 adet)

Koşma:

Kemân ebrûlarıň âhû gözleriň (Cönk, 87)

Mecnûn gibi ḳ1lar dîvâne meni

‘Âşıḳı mest ider şîrin sözleriň

Rüsvâ-y1 'aşḳ ider cihâne meni

Rızâ'nın aruz ölçüsü ile yazdığı şiirleri (1 adet)

Gazel:

Șofiyâ devrâna gel Allâh hû yâ hû diyü (Cönk, 64)

Şevḳ ile meydâne gel Allâh hû yâ hû diye

Zahmî’nin aruz ölçüsü ile yazdığı şiirleri (1 adet)

Gazel-i Müseddes (Arslan ve Doğan, 2009:772)

Dilâ tecdîd-i matem ḳıl bugün mah-1 Muḥarremdir

(Cönk, 58)
Melâik ins ile cinnî bugün hep ehl-i mâtemdir

Velâyet şâhınıň yâ hû şehîd oldug̉u bu demdir

'Adüvv-i ekberim ancaḳ benim bir iki âdemdir

Birisi Şimr-i zü'l-cevşen birisi İbn-i Mülcemdir

Bulara dâ'imâ la‘net dimek mü’mîne elzemdir

Cönkte ayrıca 11 adet müfred, 6 adet mani mevcuttur.

Sonuç

Bu çalışmada, Merzifon Cönkü adını verdiğimiz ve şahsî kütüphânemizde bulunan yazma bir nüshayı tanıtmayı amaçladık. Cönklerin ve mecmuaların yeni şairler ve şiirler keşfetmek için en uygun eserler olduğu ve bu kaynakların tamamı gün yüzüne çıkmadan tam bir Türk edebiyatı tarihi yazılamayacağı bir gerçektir. Bu amaçla 32 şairin hece veya aruzla yazdığ cönkün transkirp edilip bilim âlemine sunulması önem arz etmekteydi. Bu çalışmada eksik kalan yön, şairlerin tek tek ele alınması ve hakkında hiç çalışma bulunmayanların tespit edilmesidir. Makale boyutunu aşmak endişesi ile bu çalışmada sadece birkaç şair hakkında kısa bilgiler verilmiştir. Ancak eserin kitap olarak yayınlanması ve detaylı incelenmesi sonucunda bilinmeyen birkaç şair ve sahibini arayan pek çok şiir ortaya çıkacaktır. Çalışmamıza, Merzifon Cönkü Bağlamında Hece-Aruz Kardeşliği adını vermemizin sebeplerini sunduk. Cönkü toplayan şahsın neredeyse aruz ve hece ile yazılan şiirleri eşit tercih etmesi bu kardeşliğin en canlı belirtisidir.

Cönkteki şairlerin şiirlerini, hece ve aruz ölçüsüne göre tasnif edilerek bu ilişki daha sarih bir şekilde gözler önüne serilmiştir.

\section{Kaynaklar}

Arslan, Mehmet, Mehtap Doğan. Kerbelâ Mersiyeleri. Ankara: Grafiker Yayınları, 2009.

Bilgin, Orhan. Merzifonlu İki Şair-Eyüp SabrîHıfzi. İstanbul: Enderun Kitabevi, 1992.

Çankırılı Ahmet Talat. Tokatlı Nuri, Çankırı Matbaası, 1993.

Elçin, Şükrü. Âşık Ömer. Ankara: Kültür Ba- 
kanlığı Yayınları, 1987.

Kaya, Doğan. Kültürümüzde Cönkler ve Sivas Kaynaklı Cönkler, s.1. http://turkoloji.cu.edu.tr/ HALK\%20EDEBIYATI/dogan_kaya_conkler_ve_ onemi.pdf (E.T.: 23.01.2019)

Köksal, Mehmet Fatih. Yâ Kebîkeç-Mecmualar Arasında. İstanbul: Kesit Yayınları, 2016.

Köksal, Mehmet Fatih. Şiir Mecmuaların Önemi ve Mecmuaların Sistematik Tasnifi Projesi (MESTAP),https://mecmualar.tr.gg/MESTAP-Projesi-Hakk\%26\%23305\%3Bnda.htm\#_ftnref3 (E.T.: 15.02.2019)

Köksal, Mehmet Fatih, Mücahit Kaçar, Mevlüt İlhan. Prof. Dr. Mehmet Fatih Köksal Kütüphanesi Türkçe Yazmalar Kataloğu. İstanbul: Kesit, 2018.

Köktürk, Şahin. Cönklerden Bir Cönk Amasya Cönkü. Samsun: e-yayınevi, 2007.

Kurnaz, Cemal. Türküden Gazele Halk ve Divan Şiirinin Müşterekleri Üzerine Bir Deneme. Ankara: Akçağ, 1997.

Küçük, Sabahattin. Baki Divanı. Ankara: Türk Dil Kurumu Yayınları, 1994.

Merzifon Cönkü (Cönk), Metin Hakverdioğlu şahsî kütüphanesi.

Yılmaz, Meltem. Cönkler Üzerine Yapılan Çalışmalar, SEDAF (35): 165-196, 2016. 


\title{
MERZIFON'S CONK
}

\section{Metin HAKVERDİŎLUU}

Amasya Üniversty, metin.hakverdioglu@amasya.edu.tr

Hakverdioğlu, Metin. “Merzifon Cönkü” idil, 57 (May 2019): s. 543-558. doi: 10.7816/idil-08-57-02

\begin{abstract}
Merzifon, the largest district of Amasya, has been an important cultural center for centuries. This center has a very important place in shaping our literary life and has liked many poets and poetry art lovers. The difference of Merzifon from Amasya is that it is a town and has a position to bring together folk poetry and divan poetry. Çorum, Kastamonu, Sinop, Samsun as a large settlement on the way to such centers has brought it to this position. The town served as a resting, breathing inn on the route of the folk poets. The fact that the poets living in the eighteenth and nineteenth centuries had to stop in this environment made Merzifon the center of poets and poetry lovers. Merzifon 's poets and art lovers did not make any mistakes in hosting the folk poets who came and went, so the attraction of the center increased. The prominent names such as Dertli, Emrah, Nûrî and Aşık Ömer accepted the invitation of Merzifonlu poets like Eyüp Sabrî and added color to the art life of the center. The manuscript that we have called Merzifon Cönkü is a rare artifact created by this environment. The most interesting aspect of this work, which we have included in our library from Merzifon, is that the poems of the people and divan are recorded equally. There are dozens of poems written by folk poets as well as poems from the great divan poet like Bâkî. On the other hand, mani from koşma or dozens of poems have been brought together in this cönk. Of the thirtytwo poets, the poet, containing 161 poems, concentrated on the poems of Tokatlı Nûrî. Poems, written in koşma and mani and divan, semai, kalenderi, satranc, gazel, şarkı written in aruz. The book has a total of 98 "aruz" poems and 63 "hece" poems. In this study, we aim to present the properties of the Merzifon Intensity and the first verse units of the poems it contains.
\end{abstract}

Keywords: Merzifon's Cönk, Classical Turkish Poetry, Folk Poetry, Cönk, Hece Poetry Measure, Aruz Poetry Measure. 